\title{
TAKING STOCK OF REGULATION IN THE STATE OF NEW YORK
}

\section{MIORRIS LLEWELLYN COOIE}

PubLIC utility regulation is in urgent need of radical revision in the opinion of nearly everyone associated with the recent investigation authorized by the Legislature of the State of New York. ${ }^{2}$ It is a very significant fact that this demand for a wide variety of changes was voiced not only by every member of the Commission but almost without exception by the witnesses-if one omits the representatives of the companies to be regulated and the recent Chairman of the New York Commission. Practically no one, unless it be the private interests involved, seemed to want to sponsor regulation as now practiced. That there developed within the Commission itself differences as to the method of rehabilitation, finally resulting in majority and minority reports, was to have been expected; but the unanimity with which even the more fundamental practices of present day regulation were held to be open to change for the better could not have been foreseen.

To gain some picture of the situation which created the necessity and the demand for this investigation one must take a hasty glance at the history of regulation in New York State. As the direct outcome of an investigation of the New York Edison Company conducted in 1905 by Charles Evans Hughes as counsel for the Stevens (Senate) Committee, New York in $1907{ }^{2}$ adopted regulation by commission "by reason of the evils that existed under a system of control by the Legislature and municipalities which was haphazard and erratic. Abuses had grown up which could not effectively be met by direct legis-

\footnotetext{
* Consulting Engineer in Management, Philadelphia, Pa.; editor and co-author of PUBLIC UTILITY REGULATION (1924); author of numerous articles on public utilities.

1 The investigating Commission was appointed February 10, 1929, pursuant to Chapter 673 of the Laws of New York, 1929. It consisted of the temporary President of the Senate, John Knight, Senators Warren T. Thayer and William J. Hickey; three members of the Assembly, Speaker Joseph A. MicGinnies, Horace M. Stone and Russell G. Dunmore; and three appointees of Governor Roosevelt, Frank P. Walsh, an attorney associated for years with public causes and now resident in New York City, James C. Bonbright of the faculty of Columbia University and David C. Adie, associated with charity organization work in Buffalo.

2 Prior to this time there had been a Gas \& Electric Commission with some regulatory powers but little or no control over rates.
} 
lative control. Attempts to control by municipal subdivisions of the State were equally ineffective." ${ }^{3}$

For some years after its establishment in New York, and particularly during the term of Governor Hughes, regulation worked with fair satisfaction to the public. Some of the more outstanding abuses under the old system were promptly rectified. The fact that the Commission began its operation in what proved to be a period of falling rates helped it to gain the confidence of the public. . But perhaps its greatest source of enrly strength lay in the fact that the Commission operated primarily as an administrative agency. On its own initiative it moved to make the adjustments the demand for which had brought it into being. The almost exclusively judicial character of the later work of the Commission had not then begun to express itself.

When the War came on and prices and operating expenses generally rose, the commissions in New York and elsewhere either actively or passively blocked the demands of the companies for increased rates. After the War, however, the companies became more insistent that the higher price levels be recognized both in valuations and in the resulting tariffs. While the theory of valuation based on reproduction-cost-new less depreciation has been a factor in rate making ever since the early days of regulation, it needed the higher post-war price levels to give it vitality and secure the increasing recognition shown by the later decisions of the United States Supreme Court.

More and more in recent years the public has felt baffled in seeking to have its rights determined by a commission that looked upon itself as a court appointed solely to try issues brought before it on initiative other than its own. Further, the public has more and more felt penalized by valuations which have little relation to the amount of money actually invested in the property and by rates which no one claims have a relation to the cost of service.

This public restlessness found expression in a double leaded four column editorial advocating an inquiry into the "operation of the New York Public Service Commission" appearing in the New York World on January 21, 1929, the opening paragraph of which read:

"The high hopes with which the existing system of public utility regulation was inaugurated in this State have not been fulfilled. It is a fact beyond dispute that in certain important respects this system has broken down."

Within a few days thereafter bills calling for an investigation

3 From the majority report. See LEG. Doc. (1930) No. 75, p. 9. 
were introduced in the Legislature by both the Republican and Democratic factions. The bill that ultimately passed, and resulted in the inquiry of which this article is a review, certainly afforded every opportunity to develop the situation. One cannot but regret that it was not possible to follow the suggestion of the World that both ex-Governor Hughes and ex-Governor Smith be put on the Commission. In spite of what was on the whole an ably conducted investigation, one senses a lack of statesmanship in meeting the problems which it developed.

The Commission held hearings-about 40 in number-between October 9, 1929 and January 15, 1930, during the course of which it heard 95 witnesses. The testimony ran nearly 6,000 pages with over 200 exhibits. The record has already been issued to subscribers ${ }^{5}$ and authorization has been secured for its publication as a legislative document. The report of the Commission as signed by the six majority members has been published as Legislative Document (1930) No. 75 and with it are included (1) the minority report and recommendations of the three commissioners appointed by Governor Roosevelt, (2) a lengthy and valuable analysis of the testimony by Colonel William J. Donovan, Counsel to the Commission, and (3) several appendices covering the electric utility situation in foreign countries. A map lithographed in colors showing the territory occupied by the several operating companies in the States of New York, New Jer'sey and Pennsylvania was published as an insert in the main report. ${ }^{6}$

Credit is due to the Commission, its Counsel and its Research Director, Dr. William E. Mosher, ${ }^{7}$ for the effort constantly in evidence to bring out through the witnesses the full range of their possible contribution. There was little badgering of witnesses-only the effort to develop the situation along a broad and, it must be admitted, a complicated front. Even a casual perusal of this record shows that the American problem of regulation is not as nearly solved as is sometimes believed. ${ }^{8}$

In the early discussions of what the report of the Commission should contain there were no divisions; some very important conclusions were unanimously, even if tentatively, adopted.

${ }^{4}$ N. Y. Laws 1929 , c. 673 .

-It may be secured from the official State Stenographers, Marshall \& Munson, 150 Nassau St., New York City.

6 This may be secured from C. S. Wertsner \& Son, 50 No. 13th St., Philadelphia.

TDirector of the School of Citizenship and Public Affairs of Syracuse University and author of Elecrric UTultres-The Crisis IN Public CoNTROL (1929), which is as valuable a book on the utility situation as exists.

8."Our electrical utilities are regulated at earnings between 6 and 8 per cent on their invested capital." From pamphlet reprint of a campaign speech by Herbert Hoover dated Washington, D. C., Sept. 29, 1924. 
Before the end, however, the two factions in the Commission drew completely away from each other over the question whether "prudent investment" unimpaired or "reproductioncost-new" less depreciation should be used as the basis of valuation for rate making purposes. ${ }^{\circ}$ That there was an element of political strategy in the character of this division is too ap. parent to be ignored. It is possible that the Administration, represented by the minority, sought to emphasize, and even to exaggerate, the area of difference in order to strengthen a very handy campaign issue. On the other hand the majority showed a disposition to minimize the importance of what was involved in validating the valuation of existing property on the basis of "the law of the land." 10 According to the record there were no common findings. And yet this is far from the whole truth. If differences as to valuation could have been adjusted, a unanimous and reasonably constructive report would apparently have been possible.

As has been indicated it was the procedure to be followed in fixing the rate base which emerged as the all-important issue. In the words of the majority:

"There is no problem confronting the utility managements and the public in any way comparable to the problem of valuation. Upon its proper solution, as upon nothing else, depends the future of public utility supervision and control." 11

Likewise states the minority:

"In our opinion the greatest single weakness of the existing system of public utility regulation-and this applies not merely to New York State but to the country as a whole-lies in the hopeless difficulties inherent in the use of a physical valuation of property as a basis of rate control." 12

Later I shall try to explain why I believe the present relative importance of the valuation element in the whole regulation situation has been overemphasized. Nevertheless, in view of decisions recently rendered by a majority of the United States Supreme Court, the situation as of this date will have to be

9 Otherwise stated the question is: Shall the amount of return to bo allowed a given utility be figured on the actual fair investment in the property or on the estimated cost to reproduce the property at prico lovols existing at the time the return is determined and the rates to produco this return are adopted. In the first case the base on which the return is figured is fairly stable, i.e. obtained from the books, and the rate of roturn varied to meet conditions. In the second case the base constantly fluctuates with the price level and the rate remains more or less stable-more often at 7 per cent than otherwise.

${ }^{10}$ LEG. DoC. (1930) No. 75, p. 21.

11 Ibid. 16.

12 Ibid. 334. 
radically remodeled before regulation can be made to work with reasonable satisfaction. The investigating Commission certainly would have approved unanimously the statement quoted from the Majority Report:

"The Supreme Court, the chief source of the definitions of what constitutes value, is often divided within itself. Its decisions, taken all together, lay the ground for methods of determining values that permit of a great variety of interpretations and emphases. In these decisions intangibles are recognized, concerning which the most expert technicians fail to agree. The way is open for inflation of claims by the companies, which if court decisions be taken as a criterion sometimes run into hundreds of millions of dollars." 13

But beyond this agreement that present methods of valuation are costly and cumbersome there developed differences of a most radical character as to how a fair, workable and legally sound rate base can be established.

In the determination of "a fair return on a fair value of the property," as is held to be required by the Fourteenth Amendment, ${ }^{14}$ the Supreme Court has in the past given recognition to such factors as the original cost 15 of the property, the historical cost, the cost to reproduce the property more or less exactly, the cost to reproduce a plant giving equivalent service, the book value, the market value of the outstanding securities, etc. Each of these indices was to be given its appropriate weight in cases coming before the Court. But no formula capable of general application and suggesting the relative importance of these several factors has been forthcoming. In one case ${ }^{16}$ current reproduction cost seemed to dominate the determination of "fair value" while in others " prudent investment has received special consideration. ${ }^{18}$ In recent cases, ${ }^{10}$ however,

13 Ibid. 16.

14 Smythe v. Ames, 169 U. S. 466, 18 Sup. Ct. 418 (1898).

15 It is assumed, of course, that in reaching "fair value" an allowance for depreciation will be made no matter what variety of "cost" is used.

${ }^{16}$ Southwestern Bell Telephone Co. v. Public Service Commission of IIissouri, 262 U. S. 276, 43 Sup. Ct. 544 (1923).

${ }_{17}$ Galveston Electric Co. v. City of Galveston, 258 U. S. 388, 42 Sup. Ct. 351 (1922); Georgia Railway \& Power Co. v. Railroad Commission of Georgia, 262 U. S. 625, 43 Sup. Ct. 680 (1923).

18 The United States Supreme Court has naturally been very chary of approving actual investment, having been put on its guard in the early days of rate making by all sorts of fraudulent and excessive alleged costs. For an excellent statement on this point see People v. Willcox, $210 \mathrm{~N}$. Y. 479, 104 N. E. 911 (1914). See also Donald Richberg's brief for the city of Chicago in Peoples Gas Light \& Coke Co. v. Chicago, 309 Ill. 40, 139 N. E. 867 (1923).

19 E.g. McCardle v. Indianapolis Water Co., 272 U. S. 400, 47 Sup. Ct. 144 (1926). 
-and more particularly in the latest case ${ }^{20}$-it is claimed that present value interpreted to mean reproduction-cost-new less depreciation ${ }^{21}$ has been asserted with unmistakable emphasis in the majority opinion. Against this a minority of the Court has advocated strenuously unimpaired prudent investment as the base upon which rates should be calculated. Thus it might seem that an issue which has been discussed before the Supreme Court constantly throughout a full generation has now become very definitely joined.

This question whether reproduction cost or prudent investment shall be given preference as the rate base is generally considered the starting point in any discussion of regulation. And yet the New York investigating Commission, in the selection and interrogation of witnesses, devoted almost no attention to it. In fact the question was before the Commission at best in a very uncertain way. Such discussion as there was had really to do with the method of applying the one doctrine or the other rather than with their respective merits. There are indications that the minority, which outspokenly followed prudent investment from the beginning, failed to realize as fully as it might have the necessity for introducing into the record the bases of its faith. While it is true that the arguments for prudent investment were thoroughly developed in the very able brief, The Basis of Rate Control, prepared by Commissioner Bonbright and published as a section of the minority report, it is also true that this brief does not rest in any large degree on the testimony brought out at the hearings. In view of the basic importance of the question, as well as the fact that opinions of economists and other specialists who are known to favor the actual cost basis of rate control were not secured, the majority in control of the investigation cannot be absolved from responsibility for keeping the record feeble on this point. Doubtless, as the investigation developed, the difficulties of passing to the prudent investment basis were emphasized. But in this field no matter which way one turns apparently insuperable obstacles are encountered. If regulation should fail and be superseded by public ownership on a broad scale-the only alternative at present in sight-an entirely different but nevertheless herculean set of problems will have to be solved.

20 United Railways \& Electric Co. v. West, 280 U. S. 234, 50 Sup. Ct. 123 (1930). In view of the frequency with which this case is cited in tho testimony and in the reports of this investigation it seems to be considered as the Magna Carta of the reproduction-cost-new theory.

2I The decision does go so far as to provide for depreciation estimated on a present value basis. Such a ruling introduces elements of both engincoring and economics into accountancy. Depreciation entries will result, tho bases of which will be as elusive as will-o'-the-wisps. 
Certainly the following statement in the majority report, while factually true, does not express the total situation:

"It is significant that none of the recognized economists and price experts to whom the fundamental theory of this bill [the minority's bill designed to give effect to prudent investment] was presented were favorably disposed toward it." 2

The only witnesses who might fairly have been included under the heading of a "recognized economist and price expert," wer'e President Arthur T. Hadley, Professor Irving Fisher, Professor H. Parker Willis, and Professor Wesley C. Mitchell.

Professor Mitchell declined to express his opinion as to a proper rate base on the ground that he was not an expert on this question. Professor Fisher discussed the general principles of "reproduction costs" and "prudent investment costs" and showed the impracticability of using the former as a basis of valuation and rate making. He also showred the unfairness of varying the money incomes of common stockholders by means of a price index, while leaving bondholders, preferred stockholders, and the consumer's of public utility services partly or wholly out of account. He advocated vigorously that "prudent investment" should be talken as the basis of all rate systems and that the rates and valuations be readjusted at convenient intervals by means of an index number, so as to deal fairly with the consuming public on the one hand and with investors of all classes on the other.

Professor Willis disapproved of actual cost as the rate base, but he disapproved no less of the "present value" doctrine. Instead he favored a basis of rate control which followed his conception of the law of competitive prices. This in effect means that rates would be based on the estimated cost of reproducing the service. President Hadley, while not favoring any rate base whatever, thought that the so-called "present value" doctrine was better than the actual cost doctrine because the former was less apt to be observed in practice and would therefore allow companies to charge about what they choose.

Perhaps the attitude of the majority on this question is reflected by a statement of Dr. Mosher-the Commission's able and wholly open-minded director of research: "To expect the Commissioners to advocate a measure [again referring to the minority bill] upon which experts cannot agree, for which there is no public demand, and against which the Supreme Court has frequently ruled is, to say the least, naive." ${ }_{23}$ Laying aside the adequacy of this act to accomplish its avowed purpose, certainly it may be said that if Justices Louis D. Brandeis, Oliver

22 LEG. Doc. (1930) No. 75, p. 19.

23 See Letter to the Editor, NATION (IIay 28, 1930). 
Wendell Holmes and Harlan Fiske Stone of the United States Supreme Court had not argued continually and cogently for this same prudent investment theory, the valuation situation would not have reached the point where everybody agrees that something has to be done about it. If Theodore Roosevelt and Woodrow Wilson had not advocated prudent investment it would not now be fundamental to the Federal Water Power Act. If Gifford Pinchot, George Woodruff and Philip P. Wells had not been arguing for prudent investment for a quarter of a century it would not now be incorporated in the Pennsylvania Act authorizing the Department of Forestry to lease State lands for power purposes. ${ }^{24}$ In spite of his consistent advocacy of unimpaired prudent investment, Milo R. Maltbie is recognized as one of the nation's greatest authorities on regulation and is Chairman of the Public Service Commission of the state of New York.

Why should it be considered "naive" for statesmen to advocate for the United States a principle which by repeated Acts of Parliament has been made "the law of the land" for Great Britain? Or why should it be considered "naive" to advocate measures simply because there was perhaps very slight chance of their being passed at the particular session of the New York Legislature at which this report was to be received? The Water Power Act required 20 years for its passage through Congress.

Once having reached the unanimous conclusion that the Supreme Court decisions as to valuation for rate malking purposes practically precluded effective regulation, the Commission split six to three as to what to do about it. The majority took the position that the recent decisions favoring reproduction-costnew constituted "the law of the land" and that this theory must be part and parcel of whatever is done to give that degree of stabilization to the rate base without which it was admitted costs and rates could not satisfactorily be determined. So the majority proposed to authorize the Public Service Commission to negotiate contracts with each operating company settling the value of its plant and property on a reproduction-cost-new basis. The acceptance of these valuations was to be entirely optional with the company. But once accepted they were to remain fixed for approximately ten years except as increased by new construction or diminished by routine depreciation. Apparently adequate appropriations to cover the expense of making these valuations, over a period of three years, were provided. The majority held that the adoption of its proposal would enable the Commission to go into the valuation problem as it never had before. With actual data for the rate base of

24 Pa. Stat. (Supp. 1928) § 11130a (1923). 
any given company, with the actual investment as the basis for determining increases in such rate base during a period of ten years, and with the requirement that at the end of that period there should be a new deal in which, of course, any modifications in policy of the Supreme Court would be taken into account, some progress would surely be made. So runs the contention of the majority. The minority claims that this legislation would simply result in values "frozen" at present price levels, which are high as compared with those which may be expected to obtain during the next decade or two. Further, and of even more importance in the opinion of the minority, such a line of action would leave the main issue unsolved.

It is only fair to remind the reader that in any discussion of the proper base upon which to figure earnings and rates appropriate thereto, the interests and therefore the contentions of the principals are apt to change with the changing economic situation. Where the greater part of a given investment has been made at prices higher than those prevailing at the time the rates are to be determined, the public might be expected to seek valuations based on present value. Indeed this was exactly the contention of the public fifty years ago when railroad rates were frequently before our legislatures. On the other hand, where a large part of the investment has been made immediately before and after 1900 at price levels markedly lower than the present, as is the case with most street railroads today, it is natural for the managements of such companies to seek the use of current prices in fixing the rate base. But opportunism is not fit food for statesmanship in a technical era.

The minority looked with less finality upon the present status of valuation theory as apparently determined by Supreme Court decisions and sought to avoid reproduction-cost-new by having the Legislature authorize the Commission to make valuations on a prudent investment basis but in so doing to accept "the law of the land" for outlays already made. The minority realized that the position of the Court, as it is currently assumed to be by the general public, is based to a great extent on pure dicta-what the Court has said-rather than on what the Court has actually held. It was the theory of the minority's bill that the Supreme Court would not blithely upset a scheme of valuation for rate making purposes authorized by the Legislature.

To rectify what is wrong with public utility regulation is not an over-night job. Therefore we may well include in the whole task the problem of providing the individual states with valuation tools better than those which to date have been forged by the Supreme Court. The decisions of the Supreme Court 
are the decisions of fallible men on matters involving judgment and are therefore subject to the judgment of other men. If, as seems to be the case, the rule of reproduction-cost-new less depreciation, claimed to have been legitimatized by the Supreme Court, is unworkable as a practical matter in that it does not provide the degree of stabilization required for effective regulatory control, it would seem to be the part of wisdom to explore the various schemes by which the individual states may substitute a more workable rule. In the Dartmouth College case the Supreme Court ruled that state charters were not revocable. The states met this hurdle by inserting a revocable clause in all charters subsequently granted.

Just as the minority of the New York investigating Commission sought legislative sanction for prudent investment, so apparently the Interstate Commerce Commission is inviting Congress through legislative enactment to erect a bulwark against the current Supreme Court position. A letter recently sent by the Interstate Commerce Commission to the Interstate Commerce Committee of the Senate recommends that Congress stipulate the method by which the Commission shall value the railways for purposes of rate-making, re-capture, etc., in order to "reduce the task of bringing valuations up to date to a purely accounting process." Under the proposed method valuation could be determined at any time "by taking the cost of reproduction new at the 1914 unit prices of the property existing on the original valuation data, plus the value of the lands, adding or subtracting the subsequent net increase in the property investment account as shown by the accounts, when correctly kept, adding further a proper allowance for working capital, and deducting the balance standing in the depreciation reserve." ${ }^{25}$

In the present writer's opinion the majority of the investigating Commission erred in acquiescing in a theory of valuation under which regulation must ultimately fail. It simply accepts reproduction-cost-new with all its fictions and uncertainties, not to say injustices, as "the law of the land" and seeks some measure of stabilization through a ten year period. The reproduction-cost-new theory of valuation for rate making purposes seems wholly unworkable from an administrative point of view.26 I fully agree with the testimony of Chairman Atwill of the Massachusetts Public Service Commission that unless we can substitute for reproduction-cost-new a more stable and easily ascertained rate base, ${ }^{27}$ such as prudent investment, reg-

${ }^{25}$ Report of Wilitam J. Don.ovan, Leg. Doc. (1930) No. 75, p. 96.

26 Morris Llewellyn Cooke, Shoring up the Regulation of Electrical Utilities, (1930) 8 Harv. Bus. Rev. 316.

${ }_{27}$ "Fair value is so argumentative a term, and its determination so long 
ulation as a public policy must fail and be superceded by public ownership. The same thought was expressed by the minority:

"Unless effective regulation can be enforced the people will conclude that public ownership is the only alternative to continued exploitation by unregulated private monopoly." 2 "

But on the other hand the difficulties to be encountered in substituting another rule such as prudent investment in the face of the Supreme Court decisions are admittedly very great. In recent years suggestions as to how this might be accomplished have been multiplying. Five distinct procedures can be identified as (1) the Wells or Pennsylvania plan, (2) the Massachusetts plan, (3) the Bennett plan (Wisconsin), (4) the Bauer plan, and (5) the Bonbright plan-the last two fully developed in the testimony and in the minority report of the investigating Commission.

Under each of these plans it is contemplated that there shall be exerted some measure of "pressure" on the private companies to induce them to accept prudent investment. Some varieties of pressure are undoubtedly legitimate and would be sustained both by public opinion and by the courts. As an instance there might be cited the minority's bill to facilitate the building of publicly-owned municipal distribution systems. It does not make much difference whether the pressure be exerted by legislative fiat or by commission ruling, except that a continuing agency such as a full time commission can usually act more gracefully and in such a way as to have its acts better. understood.

The Pennsylvania plan devised by Philip P. Wells during the administration of Governor Pinchot provided that: .

"In the making and regulation of the rates of any electric utility which is hereafter incorporated, such rates shall be made or fixed as to afford such electric utility from its business as a whole if efficiently conducted, a reasonable opportunity for a return upon its net investment plus its additional fair value, if any, at a rate reasonably sufficient from time to time to attract into the enterprise new money in sufficient volume to meet the needs of its public service duty." 20

Well's plan provided for a contract under which the company accepted net investment as the rate base, i.e., prudent invest-

drawn out on any given occasion that as a practical matter it fails in anything like prompt effectiveness-and promptness is the essence of justice." Report of THE Public Service Securties CoMimittee, INyestarent Bankers Association of Amierica (May 1930).

28 LEG. Doc. (1930) No. 75, P. 245.

29 See Senate Bill No. 34 (Extraordinary Session 1926). See also Aar. ACAD. PoL. \& Soc. Sci., Giant Power (edited by Miorris Llewellyn Cooke, 1925). 
ment less depreciation or prudent investment unimpaired, for all additions to plant and property made after the execution of the contract. For property already owned on the date of the contract Wells permitted the utility to secure any valuation it could under the present "law of the land." Wells recognized the difficulties in making prudent investment retroactive but recognized as well that the electrical industry is young and has its major investments yet to make. In order to get started on the new basis he ran some risk of an excessive valuation on plant and property already acquired.

Under this plan any company not agreeing to accept prudent investment by contract within a reasonable time was to be deprived of these privileges:

(a) Eminent domain.

(b) Ownership or voting of stock, etc. in any other electric utility.

(c) Right to begin exercise of rights under municipal fr'nchise.

(d) Incorporation, renewal or amendment of charter.

(e) Merger with another utility, etc.

As a matter of fact, as a preliminary to the possible passage of this act, these and other privileges were withheld over a period of months and no relatively important public inconvenience resulted.

As explained to the investigating Commission by Messrs. Atwill and Goldberg of the Massachusetts Public Service Commission, the utilities of that state have been on a basis somewhat analogous to prudent investment for over a century. This has been effected not so much by any checking of the value of the assets as by fixing rates so as to yield on the capital stock and premium a rate of return which is varied according to the judgment of the Commission, taking into account "the efficiency of the company, the efficiency of its management, the question whether it has placed back earnings into additions to the plant, the amount of depreciation it has talken, the amount of its surplus." Only four appeals ${ }^{30}$ have been taken from Massachusetts Commission rate decisions in fifty years. In the one taken to the State Supreme Court the Commission was sustained. The three appeals taken to the Federal Courts were all withdrawn. In order to protect itself against the possible implications of recent Supreme Court decisions the Massachusetts

30 Worcester Electric Light Co. v. Atwill, 23 F. (2d) 891 (D. Mass. 1927); Cambridge Electric Light.Co. v. Atwill, 25 F. (2d) 485 (D. Mass. 1928); Haverill Gas Light Co. v. Gas and Electric Commissioners (Finally abandoned in 1914); Dunham v. Public Service Cómmissioners, 232 Mass. 309, 122 N. E. 397 (1919). 
Commission has recommended legislation somewhat along the lines of the Pennsylvania plan.

Edward Bennett, Professor of Electrical Engineering at the University of Wisconsin, has prepared an act in which it is provided:

"If at any time after the lapse of one year from the date of the passage of this statute it should be found that any public utility has failed to petition this Commission to find and declare the prudent investment base of its properties, such failure shall be taken to be prima facie evidence that public convenience and necessity warrant the operation of a competing utility or utilities in the territory or any part of the territory served by the utility so failing." 31

In some parts of the country this variety of pressure would probably be effective. But where electrical development has been at all active the time may have passed.

Under the Bauer plan the Public Service Commission would be authorized by the Legislature to make valuations of all utility property, using current Supreme Court decisions as the guide, with additions to the property to be made at actual cost. This is the Pennsylvania plan without the contract, without the consent of the company. In place of pressure on the company to be exerted by the Commission, as by withholding certificates of convenience for new construction, there is substituted the legislative fiat.

The Bonbright plan is essentially the Bauer plan but with minor changes made to meet criticisms which have developed since Dr. Bauer first promoted this idea. Among these changes is a clause which permits the shift from one basis of valuation to the other to be effected by contract.

From a more immediate point of view it seems probable that the relative importance of the valuation factor in the whole scheme of utility regulation has been greatly over-emphasized. With the public service commissions in New York and elsewhere sitting virtually as courts, and with most of their time and thought devoted to questions of valuation, nothing else could have happened. The administrative phases of their task have been correspondingly neglected. It should be noted that in undertaking to operate in this field the commissions have chosen ground where the utilities are strongest. In the last twenty years the utilities have schooled a veritable army of lawyers, accountants, "economists," public relations experts, valuation engineers, et al. in the attenuated philosophy of reproduction-cost-new ${ }^{32}$ as well as in the minutiae with which it

\footnotetext{
31 See Bennett, The Inadequacy of the Public Utilities Law of Wisconsin, UNIVERSITY OF Wisconsin Studies IN Electrical EngineEriNg, Report No. 18.

32 See Cooke, op. cit. supra note 26.
} 
is made effective. Hence the commissions would be well advised from the standpoint of strategy-if for no other reasonto seek other ground on which to set up the controls needed for the protection of the public interest.

Given a commission with the ambition to make regulation effective and with reasonable appropriations at its disposal, it is the writer's opinion that a very important advance can be made within the provisions of any of the more comprehensive regulatory acts and in spite of the immediate difficulties raised by recent Supreme Court decisions. A vigorous administrative attitude toward accounting-including the classification of accounts, reporting, standardization and simplification of rate structures, cost finding, consolidations, mergers and other intercompany relationships-accompanied by an entirely unknown degree of publicity would effect something akin to a revolution. If the present foggy mass of uncertainties concerning the management and business status of utilities were replaced by definite, understandable facts the basis for many disagreements in judgment would disappear. The commissions must take into their confidence both the legislature for whom they act and the public whose interests they are supposed to protect. A more aggressive attitude on the part of the New York Commission will be facilitated by a considerable increase in its appropriation making possible the addition of 50 or 60 employees. This, the first important increase in its staff since regulation was established, is a result of the recent investigation.

Under the variety of accounting methods permitted by our commissions, many of the facts most significant from a public point of view have been entirely covered up. Through the frilure properly to segregate capital and operating expenditures under the major headings of generation, transmission, distribution and general, many of the commonly accepted statistics of the industry are misleading. The securing of costs has been made all but impossible. All this was very adequately covered by Judson C. Dickerman in his report to the investigating Commission entitled Annual Reports Required of Public Utilities by State Public Service Commissions, ${ }^{33}$ which was a discussion of the objectives in requiring, and of the methods of obtaining, reports useful for regulating purposes. As pointed out in the minority report, the New York Commission does not regulate the amount of the accrued depreciation reserve nor does it determine the annual return and charge to the reserve. All this is left entirely to the discretion of the company, and each company follows its own policy-a policy apt to change with the necessities of the moment.

Counsel Donovan in his report recommends improvements in

${ }^{33}$ Unfortunately this report has not as yet been published. 
statistics, but as to the possibility of practicing cost finding in the electrical industry he advocates only further research. In justification he cites a recent statement of Commissioner Joseph B. Eastman of the Interstate Commerce Commission to the effect that much must be done along lines of research before cost keeping can be generally introduced as a feature of railroad operation. ${ }^{34}$ He failed to notice, however, that in the same memorandum Commissioner Eastman commented very favorably upon a system of cost finding in the electrical industry fully described in testimony before the Interstate Commerce Commission. ${ }^{35}$ There are many reasons why the problem of cost finding on steam railroads differs radically from that on electrical utilities. Only through cost finding can justice be done as between different classes of consumers. ${ }^{30}$

The majority report recommends the appointment of "a divisional head in the Public Service Commission to be responsible for stimulating a plan of area development of ruxal electrification." ${ }^{37}$ This is especially interesting as general rural electric service can only be effected through development on an area basis. The territory must be completely covered if construction costs are to be kept at a minimum. What has come to be known as the Adirondack Plan for rural electrical development, which is mentioned with approval in the majority report, is not rural electrification in the sense that the term is used in Ontario, or in Sweden, Bavaria or even parts of France where over great areas practically every farm is connected. In the half of Alsace which is served from Strassburg every rural home has service. Such a situation is not unusual in Europe. The customers of the Adirondack Plan are very largely the residents of unincorporated villages or torms, or of areas immediately adjacent thereto.

In discussing rural electrification (statistics as furnished by the Empire State Gas \& Electric Association) mention is made of densities of from 17 to 19 customers to the mile. Densities do not run anything like this in farming districts. In Ontario

\footnotetext{
${ }^{44}$ Eastman, General Review of Accounting Rules for Stcam Railroads, REPORT IN EX PARTE 91 (Aug. 15, 1929).

${ }_{35}$ Hudson W. Reed, Cost Finding for the Electrical Utilitics, BuzLetix of THE TAYLOR SocIETY (April 1929). Engineering Societies Bldg., 29 W. 39 St., New York City.

${ }^{36}$ See Worcester Electric Light Co. v. Atwill, supra note 30. Mraster's decision filed February 11, 1929.

37 One of the enacted bills provides that the Public Service Commission "shall appoint a qualified person whose duty it shall be to formulnte and encourage the carrying out of plans of rural electrification, to malie research on area developments, line problems, methods of financing increased use of farm appliances and similar matters, and to hold hearings in connection with proposed measures for accomplishing the above-named objects." An adequate appropriation for carrying on the work was provided.
} 
rural rates are based on three to a mile and over. General Rule No. 27 of the Pennsylvania Public Service Commission, passed during Governor Pinchot's term of office, provided that there should be no extra charge unless the number of customers was less than three to the mile.

Counsel Donovan says in his report that "a full use of electricity is not approached in areas where the total cost of service is above 6 cents per k.w.h. Total costs refers not only to the energy charge but to line extension charges as well." ss Such rates are not generally feasible under the Adirondack Plan. Assuming one customer per mile, under the Adirondack Plan the monthly minimum is stated to be $\$ 24.00$. This implies a customer investment of about $\$ 2600$ to the mile. ${ }^{30} \$ 1100$ to the mile is a line cost which can easily be obtained in most rural areas, and $\$ 100$ will ordinarily cover the cost of the transformer and other items required for an individual service.

Some idea of the distance we have yet to go in effecting rural electrification is furnished by this statement of Otto M. Rau who made the rural electrification study for the investigating Commission:

"In the absence of definite data such as will result from the forthcoming U. S. Census one hesitates to be too definite about the percentage of farms which have service. My judgment, however, is that this percentage does not exceed fifteen and may not be above twelve. The figures issued by the companies are undoubtedly too inclusive." 40

The majority report carried a recommendation for a commission to study and report upon interstate problems affecting regulation, including the feasibility of action with neighboring states through compacts as provided for by the Federal Constitution. It was suggested that the same body make a general survey of the power needs of New York and consider the possibility of unifying the necessary service with those of other states. Unfortunately no legislative action on this was taken.

A large number of bills carrying out the ideas of both the majority and minority were introduced into the Legislature. Of those advocated by the majority 27 were passed ${ }^{41}-$ many of them varying widely from the form in which they were introduced. Of the four bills of major importance which were passed, the first provided for a statewide general valuation of

${ }^{38}$ LEG. DoC. (1930) No. 75, p. 180.

$39 \$ 24$ times 12 months gives as an annual chargo $\$ 288$ which divided by 11 per cent assumed as an allowance for fixed charges-including intorest, taxes, depreciation, etc.,-gives a cost of approximately $\$ 2600$ a mile. $\$ 1600$ stated to be the cost per mile used in arriving at theso rates would imply fixed charges 18 per cent-an unthinkable allowance.

40 See page 1 of this report, which has not been published.

41 N. Y. Laws 1929 , no. $373,760-761,773-793,829,850,865$. 
utility properties; the second, for rate-making contracts between the state and the companies; the third, for the creation of a public defender in utility cases; and the fourth, for the extension of control over contracts with holding and affiliated companies. Governor Roosevelt vetoed the first three of these bills. The accompanying messages will prove of very great interest to any student of regulation. It is possible that the bill giving to the Public Service Commission considerably more power in dealing with holding companies, however, will prove to be the outstanding accomplishment of this investigation. Holding companies thoroughly dominate the policy of the operating companies in almost every important direction. It is probable that a good deal of legislative experimentation will be required before effective control over holding company operations is established. It will be interesting to see how effective these new efforts at control prove to be.

It is highly significant that even the recommendations of the majority as to legislation-many of them tacitly concurred in by the minority-were opposed by the private companies in toto. The attitude of the acknowledged leaders of the industry appeared to be against any effort to strengthen regulation, in fact, to be against any change whatsoever.

The thoroughness of the investigation and the publicity which its deliberations and findings have received certainly put the issues in the hands of the public in a new way. But whether it is humanly possible to establish a generally effective regulatory control in this situation-admitted almost unanimously to require a new deal-is decidedly open to doubt. The very dynamics of the electrical industry discourage interference whatever the purpose. Power-the master-key to industrial progress and material well-being-is only at the threshold of its infinite usefulness. No industry ever commanded the services of such an army of educated and skilled employees. Technical research already organized along a broad front yields immediate and abundant returns. Capital is attracted to the various branches of the industry-operating and manufacturing-in unprecedented volume. The accommodation of public relations on a national as well as an international scale has been carried far. The present-day tempo of corporate organization offers rewards "beyond the dreams of avarice" to those at key positions. Can or cannot such an enterprise in private hands be controlled in the public interest? This in brief is the query posed by the New York investigation.

${ }^{42}$ The effectiveness of this new act-much amended in its passage through the Legislature-has been questioned by the Public Service Commission in its recent refusal to permit the Brooklyn Union Gas Company to sell its Greenpoint coke oven plant to a subsidiary of the Koppers Company. 